$\begin{array}{llll}\sum_{\text {Kai-Håkon Carlsen }} & \begin{array}{l}\text { Department of Paediatrics, } \\ \text { Oslo University Hospital, } \\ \text { Oslo, Norway }\end{array} & \begin{array}{l}\text { Oslo University Hospital, } \\ \text { Rikshospitalet, Department } \\ \text { of Paediatrics, P.O.Box 4950 } \\ \end{array} \\ & \begin{array}{l}\text { Nydalen, O424 Oslo, } \\ \text { Norway }\end{array}\end{array}$

\title{
Mechanisms of asthma development in elite athletes
}

\section{Summary}

Exercise-induced bronchoconstriction is caused by heat loss and water loss through respiration during exercise, leading to mediator release in the airways and to increased parasympathetic nervous activity in the airways, thereby causing constriction of bronchial smooth muscle and increased bronchial secretions as well as vasodilation in the bronchial vessels. Development of asthma and bronchial hyperresponsiveness in the competing elite athlete is presently considered to be caused by the frequently repeated increased ventilation occurring during training and competitions. Usually, the endurance athlete is at risk; and the risk is increased by repeated exposure to environmental factors such as cold air (cross-country skiers and other winter athletes), organic chlorine compounds (swimmers and other water athletes), pollution (long-distance runners and cyclists) to name a few.

\section{Aims}

$\odot$ The pathogenic mechanisms, including epithelial damage and increased airways inflammation, causing asthmatic symptoms and bronchial hyperresponsiveness are discussed.

๑ The factors associated with different sports are discussed.

\section{Exercise-induced asthma and athlete's asthma}

Exercise-induced asthma (EIA) is a frequently occurring manifestation of asthma in childhood, adolescence and in adult age [1]. It was described and defined 100 years A.D. by Araeteus the Cappodican: "If from running, gymnastic exercises or any other work, the breathing become difficult, it is called asthma $(\alpha \sigma \theta \mu \alpha)$ " [2]. The first modern scientific works on EIA were published by JONES and colleagues about 50 years ago $[3,4]$. Thereafter, GODFREY, through his two research fellows, SILVERMAN and ANDERSON [5-8], clarified different aspects of EIA and exercise tests. The importance of enabling asthmatic children to
Statement of interest K-H. Carlsen has received fees for lectures and consulting from MSD, GSK, Nycomed and Novartis during the last five years. He has received funding for research and for research fellows from Helse Sør Øst, one of the Norwegian State Health authorities, and from Klosterstiftelsen.
HERMES syllabus link: module B.1.1 
master EIA was gradually realised [9], and is presently among the main aims of all major guidelines of treatment of childhood asthma [10-13].

Later on, the realisation of the frequent occurrence of asthma among athletes came gradually. First, we showed that intensive exercise increased bronchial hyperreponsiveness (BHR) among swimmers, with the increase correlating to the exercise load [14]. LARSSON et al. [15] reported the high occurrence of BHR and asthma among crosscountry skiers in Sweden and HEIR and LARSEN [16] the influence of training intensity, airways infections and environmental conditions on BHR in young Norwegian conscripts in a special cross-country skiing unit. WILBER et al. [17] later reported similar findings in US Olympic winter sport athletes confirmed by further studies by RundeLl et al. [18]. Helenius and colleagues $[19,20]$ reported similar findings in elite endurance summer athletes. After these reports, to what extent can we explain this increased occurrence of asthma and $\mathrm{BHR}$ among elite endurance athletes?

\section{Mechanisms of athletes' asthma}

EIA is well described in asthmatic children. Two main theories have been presented and debated as to the cause of EIA in asthmatic children [21-25]. Through the respiration the inhaled air is warmed up to $37^{\circ} \mathrm{C}$ and is fully saturated with vapour. Physical activity increases minute ventilation, increasing with the intensity of the physical activity.

This causes increased water and heat loss through the respiration. The airways are cooled

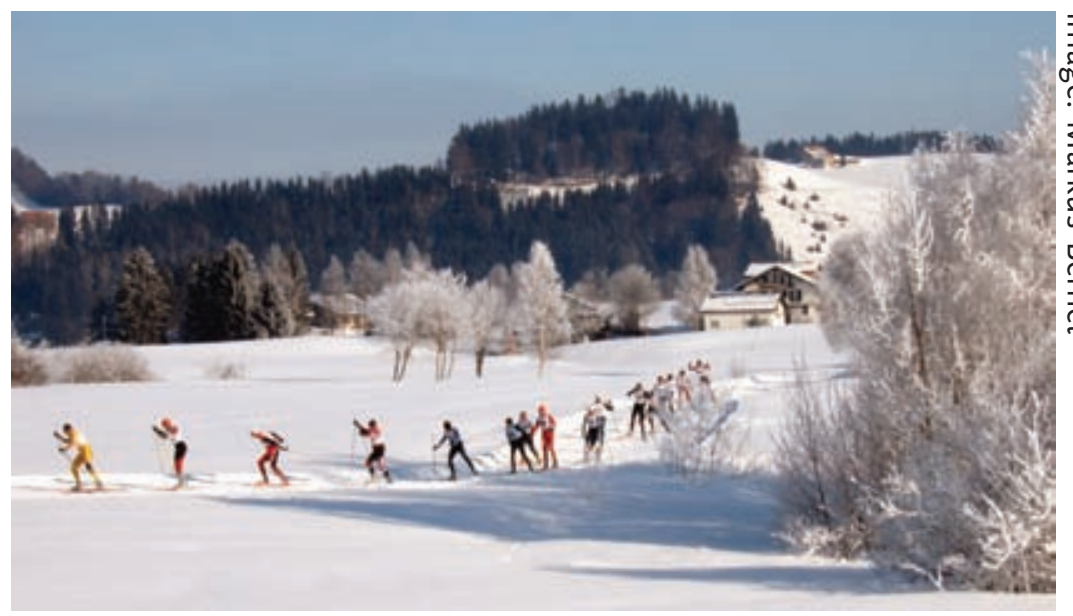

resulting in reflex parasympathetic nerve stimulation causing bronchoconstriction and, at first, reflex vasoconstriction of bronchial venules to conserve heat. At cessation of exercise, the increased ventilation ceases and so does the cooling stimulus, resulting in a rebound vasodilatation. This results in both smooth muscle constriction, due to nerve stimulation, and mucosal oedema, due to vasodilatation in susceptible individuals [26], reducing the size of the bronchial lumen with increased airways resistance [27].

On the other hand, the increased water loss caused by the increased minute ventilation is considered more important through increasing the osmolality in the extracellular fluid of the bronchial mucosal membranes. The water loss from the bronchial mucosa induces an efflux of intracellular water to the extracellular space [28] causing an intracellular increase in ion concentration [29]. This process result in mediator release; both newly formed eicosanoids [30] and preformed mediators, such as histamine, from intracellular granules are released and cause bronchoconstriction. It is suggested that cold air exerts its effect through its low content of water, thus participating in the drying of the respiratory mucosa [28].

The first report that BHR increased after heavy exercise was made on adolescent swimmers (12-18 years of age) swimming 3,000 metres. The increase in bronchial responsiveness correlated with the increase in exercise load (increase in blood lactate) in both asthmatic and healthy swimmers [14]. Later SUE-CHU et al [31]. showed that adolescent cross-country skiers (ski-gymnasts) during one competitive winter season developed signs of inflammation (lymphoid follicles and deposition of tenascin) in their bronchial biopsies independent of being asthmatics or not. Recently, these findings in bronchial biopsies from cross-country skiers was confirmed by similar findings in swimmers [32].

In exercising animals, inflammatory changes in the airways have been found. Furthermore, epithelial damage is a repeated finding. Mice, exercised by running, developed inflammation and epithelial damage in their airways compared with sedentary mice [33]. This was also found in Alaskan sledge dogs, examined by bronchoscopy and bronchoalveolar lavage before and after a sledge race across Alaska [34]. The epithelial damage has also been found to be of major importance in experimental 
studies [35], suggesting this to be the primary lesion in asthma and exercise-induced bronchoconstriction (EIB).

Positive metacholine bronchial challenges were found more often in competitive swimmers and winter sport athletes compared with healthy controls [36]. Furthermore, positive tests for eucapnic voluntary hyperpnoea were found in comparable numbers [37]. Inflammatory markers in induced sputum with increased neutrophil cell counts in induced sputum were found both in swimmers and winter sport athletes, and the neutrophil counts correlated to number of training hours per week in both groups [36]. Eosinophil counts were increased in swimmers in particular, as also was number of bronchial epithelial cells [36].

Amateur endurance runners had increased number of bronchial epithelial cells and apoptosis of bronchial cells in induced sputum developing through repeated half-marathon races, in addition to increased serum levels of $\mathrm{CC}_{16}$ and increased supernatant interleukin (IL)-8 levels in induced sputum [38]. Also, after exercise, urinary levels of $\mathrm{CC}_{1} 6$ increased, but the levels were reduced when the study subjects inhaled warm, humid air during running [39], whereas urinary $\mathrm{CC}_{16} 6$ levels were increased after performing a eucapnic voluntary hyperpnoea test with dry air whether they had a positive test with bronchial constriction or not [40]. This is taken as a sign of lung epithelial stress after exercise causing bronchial constriction. Similarly the effect upon urinary $\mathrm{CC}_{16} 6$ levels was examined using an exercise test in swimmers compared with a mannitol test. Again there were increased $\mathrm{CC}_{16} 6$ levels in the swimmers after exercise both after positive and negative response, but not after the mannitol test [41]. Furthermore, HaLLSTRAND [42] found increased number of columnar epithelial cells in induced sputum of asthmatic patients with EIB, compared with asthmatic patients without EIB, and also reported increased expression as measured by polymerase chain reaction of the gel-forming mucin, MUC ${ }_{5} A C$, in induced sputum. Also the levels of supernatant cystienyl leukotrienes and the ratio of cysteinyl leukotrienes to prostaglandins were higher in patients with EIB [42]. Furthermore, the number of columnar epithelial cells were related to degree of EIB and associated with the supernatant sputum levels of cysteinyl leukotrienes and histamine [43]. These findings

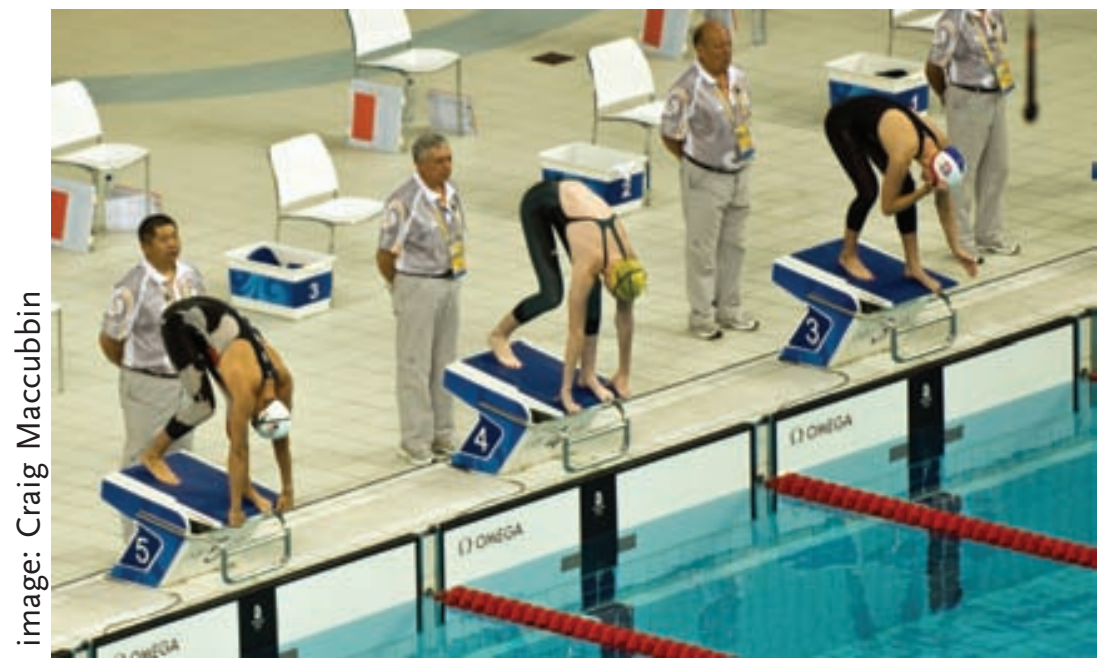

indicate an epithelial damage in the respiratory mucous membranes with mucin hyperproduction and a link from epithelial damage to increased airways inflammation through the presence of increased levels of cysteinyl leukotrienes and histamine in induced sputum as well as increased expression of MUC5AC [43].

The link between respiratory epithelial damage and increased airways inflammation is further strengthened by reports of epithelial damage in asthma is linked to increased secretion of IL-17 and IL-22, and that IL-17 and IL-22 production by T-helper 17 cells plays a critical role in established asthma [44].

Extracellular water movement across cell membranes is an important mechanistic part of the pathogenesis of EIA [28]. Aquaporin is a channel for aqueous water transport driven by osmotic forces generated by sodium and

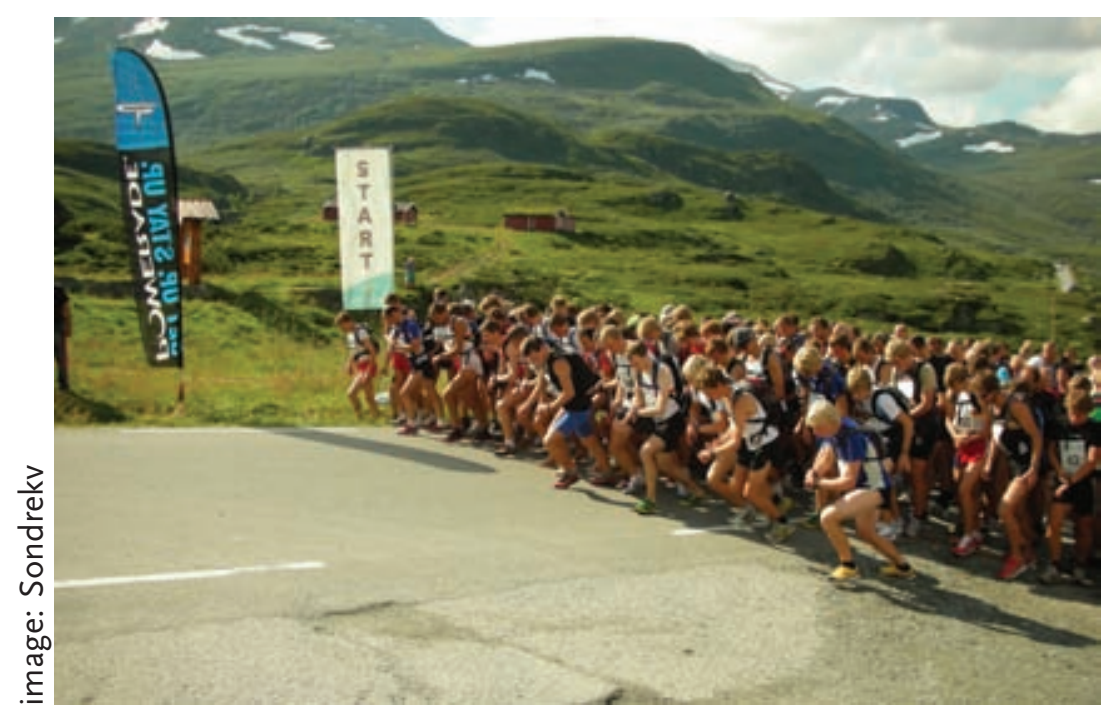




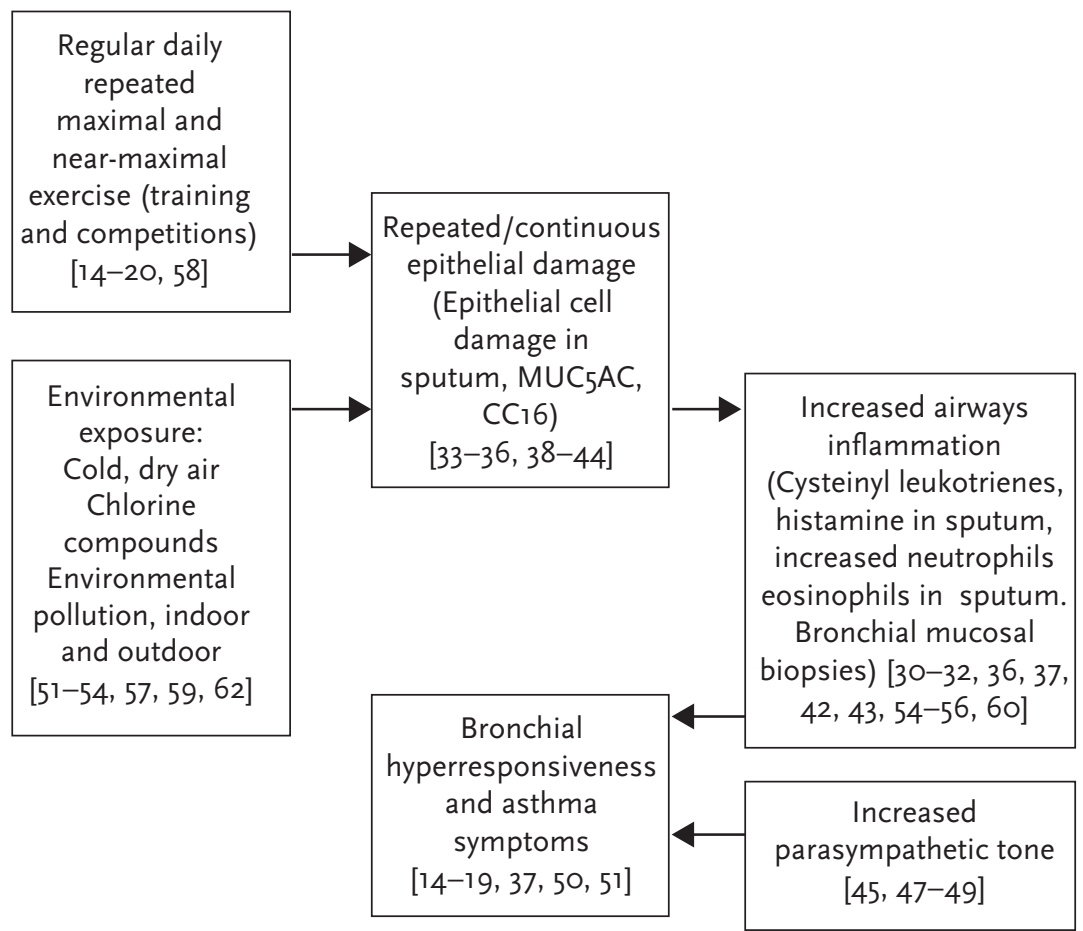

Figure 1

Factors involved in asthma development in elite atheletes.

chlorine ions and expressed in respiratory subepithelial glandular cells and alveolar type-1 cells of the lungs [45]. Mice lacking the gene for the aqueous water channel aquaporin (Aqp)-5 exhibit metacholine-induced bronchiolar hyperresponsiveness compared with normal mice [46]. PARK et al. [45] found a relationship between metacholine bronchial responsiveness and diminished pilocarpine induced sweat secretion, tearing rate and salivary flow-rate in healthy athletes, indicating an autonomic dysfunction.

Intensive and regularly repeated training influences autonomic regulation. FILIPE et al. [47] demonstrated increased parasympathetic activity in athletes, especially in endurance runners by pupillometry. Also KNOPFLI and colleagues [48, 49] in two studies reported higher parasympathetic nervous activity in top cross-country skiers and in training children using a 4 -second exercise test and influence upon $R-R$ distance in electrocardiogram.

The training environment is important for the adolescent athlete. Due to regular exercise up to twice daily with increased minute ventilation especially when training endurance, the athlete has a higher exposure to environmental air and possible pollutants and chemicals in the surrounding air.
As stated, young competitive swimmers develop BHR at an earlier age, earlier than competitive cross-country skiers [50, 51]. Exposure for swimming pools has been reported to increase asthma prevalence and exerciseinduced asthma in Belgian children [52], even though a large British birth cohort study contradicted this finding and found cumulative swimming to be associated with increased lung function and decreased risk of asthma symptoms, especially in children with preexisting respiratory illness [53]. Several studies have reported increased neutrophils and eosinophils in induced sputum from competitive swimmers [54, 55] and frequently bronchial hyperresponsiveness [50, 54, 55]. Increased leukotriene $\mathrm{B}_{4}$ levels in exhaled breath condensate was reported in Italian elite swimmers [56]. The environmental agent active in swimming pools is organic chlorine products, thought to cause airways inflammation and bronchial hyperresponsiveness [57].

Different types of sport will have different environmental exposures. Cross-country skiers are repeatedly exposed to cold air [58], athletes training and competing in ice rinks may be exposed to NOx from the freezing machinery as well as to ultrafine particles from the resurfacing machines [59] in agreement with reports of high asthma prevalence among ice-hockey players [60] and figure skaters [61].

A study from South California (USA) including 3,535 children living in six areas with a high pollution levels (ozone) and six with low pollution levels, reported after a 5-year followup that children actively participating in more than three types of sports in areas with high ozone levels had an increased risk of asthma. Participating in sports in areas with low ozone levels gave no increased risk of asthma [62]. The mechanisms and factors working together in developing asthma in elite athletes have been summarised in figure 1 .

It is thus clear that the environmental conditions in which sports and training are practised, is important for the respiratory health of the adolescent athlete. Pollution and harmful chemicals in the environmental air increase the risk for asthma development and BHR in the competing athlete. The effective ventilation of swimming pools is important, and effort should be made to develop not harmful methods of disinfection of the water in swimming pools. Cross-country skiing competitions should not be carried out in too cold environments (not below $-15^{\circ} \mathrm{C}$ ), and 
endurance sports should not be carried out in areas with high air pollution. For the allergic athletes, exposure to aeroallergens may worsen asthma symptoms, and the presence of concomitant allergic rhinitis may reduce quality of life and sports performance [63].
It is thus important that consideration to environmental exposure including climatic conditions is taken when planning sports events, also including when designing arenas for sports events, like swimming pools, ice rinks and others.
References

1. Lee TH, Anderson SD. Heterogeneity of mechanisms in exercise-induced asthma. Thorax 1985; 40: 481-487.

2. Adams F. The extant works of Aretaeus, the Cappodician London, The Sydenham Society, 1856; 316--319.

3. Jones RS, Buston MH, Wharton MJ. The effect of exercise on ventilatory function in the child with asthma. Br J Dis Chest 1962; 56: 78-86.

4. Jones RS, Wharton MJ, Buston MH. The place of physical exercise and bronchodilator drugs in the assessment of the asthmatic child. Arch Dis Child 1963; 38: 539-545.

5. Anderson SD, Silverman M, Tai E, et al. Specificity of exercise in exercise-induced asthma. Br Med J 1971; 4: 814-815.

6. Silverman M, Konig P, Godfrey S. Use of serial exercise tests to assess the efficacy and duration of action of drugs for asthma. Thorax 1973; 28: $574-578$.

7. Godfrey S, Anderson SD, Silverman M. Physiologic aspects of exercise-induced asthma. Chest 1973; 63: Suppl., 37S

8. Silverman M, Anderson SD. Standardization of exercise tests in asthmatic children. Arch Dis Child 1972; 47: 882-889.

9. Strunk RC, Mrazek DA, Fukuhara JT, et al. Cardiovascular fitness in children with asthma correlates with psychologic functioning of the child. Pediatrics 1989; 84: 460-464.

10. Bacharier LB, Boner A, Carlsen $\mathrm{KH}$, et al. Diagnosis and treatment of asthma in childhood: a PRACTALL consensus report. Allergy 2008; 63: 5-34.

11. Dahl R, Bjermer L. Nordic consensus report on asthma management. Nordic Asthma Consensus Group. Respir Med 2000; 94: 299-327.

12. British guideline on the management of asthma. Thorax 2003; 58: Suppl. 1, i1-i94.

13. Global initiative for asthma (GINA). Global Strategy for Asthma Mangement and Prevention. Available from www.ginasthma.org/uploads/users/files/ GINA_Report_2011.pdf Date last updated: December 2011.

14. Carlsen $\mathrm{KH}$, Oseid $\mathrm{S}$, Odden $\mathrm{H}$, et al. The response to heavy swimming exercise in children with and without bronchial asthma, In: Morehouse CA, ed. Children and Exercise XIII. Champaign, Human Kinetics Publishers, Inc. 1989; 351-360.

15. Larsson K, Ohlsen $\mathrm{P}$, Larsson L, et al. High prevalence of asthma in cross country skiers. $B M$ 1993; 307: 1326-1329.

16. Heir T, Larsen S. The influence of training intensity, airway infections and evironmental conditions on seasonal variations in bronchial responsiveness in cross-country skiers. Scand J Med Sci Sports 1995; 5: 152-159.

17. Wilber RL, Rundell KW, Szmedra L, et al. Incidence of exercise-induced bronchospasm in Olympic winter sport athletes. Med Sci Sports Exerc 2000; 32: 732-737.
18. Rundell KW, Im J, Mayers LB, et al. Self-reported symptoms and exercise-induced asthma in the elite athlete. Med Sci Sports Exerc 2001; 33: 208-213.

19. Helenius IJ, Tikkanen HO, Sarna S, et al. Asthma and increased bronchial responsiveness in elite athletes: atopy and sport event as risk factors. J Allergy Clin Immunol 1998; 101: 646-652.

20. Helenius I, Haahtela T. Allergy and asthma in elite summer sport athletes. J Allergy Clin Immunol 2000; 106: 444-452.

21. McFadden ER Jr, Ingram RH Jr. Exercise-induced asthma: observations on the initiating stimulus. $N$ Engl J Med 1979; 301: 763-769.

22. McFadden ER Jr, Lenner KA, Strohl KP. Postexertional airway rewarming and thermally induced asthma. New insights into pathophysiology and possible pathogenesis. J Clin Invest 1986; 78: 18-25.

23. Linn WS, Shamoo DA, Anderson KR, et al. Effects of heat and humidity on the responses of exercising asthmatics to sulfur dioxide exposure. Am Rev Respir Dis 1985; 131: 221-225.

24. Smith CM, Anderson SD, Walsh S, et al. An investigation of the effects of heat and water exchange in the recovery period after exercise in children with asthma. Am Rev Respir Dis 1989; 140: 598-605.

25. Anderson SD, Daviskas E. The airway microvasculature and exercise induced asthma. Thorax 1992; 47: 748-752.

26. Deal EC Jr, McFadden ER Jr, Ingram RH Jr, et al. Role of respiratory heat exchange in production of exercise-induced asthma. J Appl Physiol 1979; 46: $467-475$.

27. McFadden ER Jr, Nelson JA, Skowronski ME, et al. Thermally induced asthma and airway drying. Am J Respir Crit Care Med 1999; 160: 221-226.

28. Anderson SD, Daviskas E. The mechanism of exercise-induced asthma is. J Allergy Clin Immunol 2000; 106: 453-459.

29. Eveloff JL, Warnock DG. Activation of ion transport systems during cell volume regulation. Am J Physiol 1987; 252: $F_{1}-F_{10}$.

30. Hallstrand TS, Henderson WR Jr. Role of leukotrienes in exercise-induced bronchoconstriction. Curr Allergy Asthma Rep 2009; 9: 18-25.

31. Sue-Chu M, Karjalainen EM, Altraja A, et al. Lymphoid aggregates in endobronchial biopsies from young elite cross-country skiers. Am J Respir Crit Care Med 1998; 158: 597-601.

32. Bougault $\mathrm{V}$, Loubaki L, Joubert $\mathrm{P}$, et al. Airway remodeling and inflammation in competitive swimmers training in indoor chlorinated swimming pools. J Allergy Clin Immunol 2012; 129: 351-358.

33. Chimenti L, Morici G, Paterno A, et al. Endurance training damages small airway epithelium in mice. Am J Respir Crit Care Med 2007; 175: 442-449. 
34. Davis MS, McKiernan B, McCullough S, et al. Racing Alaskan sled dogs as a model of "ski asthma". Am J Respir Crit Care Med 2002; 166: 878-882.

35. Freishtat RJ, Watson AM, Benton AS, et al. Asthmatic airway epithelium is intrinsically inflammatory and mitotically dyssynchronous. Am J Respir Cell Mol Biol 2011; 44: 863-869.

36. Bougault V, Turmel J, St-Laurent J, et al. Asthma, airway inflammation, and epithelial damage in swimmers and cold-air athletes. Eur Respir J 2009; 33: $740-746$.

37. Bougault $V$, Turmel J, Boulet LP. Bronchial challenges and respiratory symptoms in elite swimmers and winter sport athletes: airway hyperresponsiveness in asthma: its measurement and clinical significance. Chest 2010; 138: 31S-37S.

38. Chimenti L, Morici G, Paterno A, et al. Bronchial epithelial damage after a half-marathon in nonasthmatic amateur runners. Am J Physiol Lung Cell Mol Physiol 2010; 298: L857-L862.

39. Bolger C, Tufvesson E, Anderson SD, et al. The effect of inspired air conditions on exercise-induced bronchoconstriction and urinary $\mathrm{CC}_{1} 6$ levels in athletes. J Appl Physiol 2011; 111: 1059-1065.

40. Bolger C, Tufvesson E, Sue-Chu M, et al. Hyperpneainduced bronchoconstriction and urinary $\mathrm{CC}_{1} 6$ levels in athletes. Med Sci Sports Exerc 2011; 43: 1207-1213.

41. Romberg K, Bjermer L, Tufvesson E. Exercise but not mannitol provocation increases urinary Clara cell protein (CC16) in elite swimmers. Respir Med 2011; 105: 31-36.

42. Hallstrand TS, Moody MW, Aitken ML, et al. Airway immunopathology of asthma with exercise-induced bronchoconstriction. J Allergy Clin Immunol 2005; 116: $586-593$

43. Hallstrand TS, Moody MW, Wurfel MM, et al. Inflammatory basis of exercise-induced bronchoconstriction. AmJ Respir Crit Care Med 2005; 172: 679-686.

44. Besnard AG, Togbe D, Couillin I, et al. Inflammasome-IL-1-Th17 response in allergic lung inflammation. J Mol Cell Biol 2012; 4: 3-10.

45. Park C, Stafford C, Lockette W. Exercise-induced asthma may be associated with diminished sweat secretion rates in humans. Chest 2008; 134: 552-558.

46. Nejsum LN, Kwon TH, Jensen UB, et al. Functional requirement of aquaporin-5 in plasma membranes of sweat glands. Proc Natl Acad Sci USA 2002; 99: 511-516.

47. Filipe JA, Falcao-Reis F, Castro-Correia J, et al. Assessment of autonomic function in high level athletes by pupillometry. Auton Neurosci 2003; 104: 66-72.

48. Knopfli BH, Bar-Or O. Vagal activity and airway response to ipratropium bromide before and after exercise in ambient and cold conditions in healthy cross-country runners. Clin J Sport Med 1999; 9: 170-176.
49. Knopfli BH, Bar-Or O, Araujo CG. Effect of ipratropium bromide on EIB in children depends on vagal activity. Med Sci Sports Exerc 2005; 37: 354-359.

50. Stadelmann K, Stensrud T, Carlsen KH. Respiratory symptoms and bronchial responsiveness in competitive swimmers. Med Sci Sports Exerc 2011; 43: 375-381.

51. Stensrud T, Mykland KV, Gabrielsen K, et al. Bronchial hyperresponsiveness in skiers: field test versus methacholine provocation? Med Sci Sports Exerc 2007; 39: 1681-1686.

52. Bernard A, Carbonnelle S, de Burbure C, et al. Chlorinated pool attendance, atopy, and the risk of asthma during childhood. Environ Health Perspect 2006; 114: 1567-1573.

53. Font-Ribera L, Villanueva CM, Nieuwenhuijsen MJ, et al. Swimming pool attendance, asthma, allergies, and lung function in the Avon Longitudinal Study of Parents and Children cohort. Am J Respir Crit Care Med 2011; 183: 582-588.

54. Moreira A, Delgado L, Palmares C, et al. Competitive swimmers with allergic asthma show a mixed type of airway inflammation. Eur Respir J 2008; 31: 1139-1141.

55. Helenius IJ, Rytila P, Metso T, et al. Respiratory symptoms, bronchial responsiveness, and cellular characteristics of induced sputum in elite swimmers. Allergy 1998; 53: 346-352.

56. Piacentini GL, Rigotti E, Bodini A, et al. Airway inflammation in elite swimmers. J Allergy Clin Immunol 2007; 119: 1559-1560.

57. Weisel CP, Richardson SD, Nemery B, et al. Childhood asthma and environmental exposures at swimming pools: state of the science and research recommendations. Environ Health Perspect 2009; 117: 500-507.

58. Heir T, Oseid S. Self-reported asthma and exerciseinduced asthma symptoms in high-level competetive cross-country skiers. Scand J Med Sci Sports 1994; 4: 128-133.

59. Rundell KW. High levels of airborne ultrafine and fine particulate matter in indoor ice arenas. Inhal Toxicol 2003; 15: 237-250.

6o. Lumme A, Haahtela T, Ounap J, et al. Airway inflammation, bronchial hyperresponsiveness and asthma in elite ice hockey players. Eur Respir J 2003; 22: 113-117.

61. Mannix ET, Farber MO, Palange $P$, et al. Exerciseinduced asthma in figure skaters. Chest 1996; 109: 312-315.

62. McConnell R, Berhane K, Gilliland F, et al. Asthma in exercising children exposed to ozone: a cohort study. Lancet 2002; 359: 386-391.

63. Bonini S, Bonini M, Bousquet J, et al. Rhinitis and asthma in athletes: an ARIA document in collaboration with GA2LEN. Allergy 2006; 61: 681-692. 